НЕЖЕЛАНОТО СЪБИТИЕ В МЕДИЦИНАТА

В КОНТЕКСТА НА ГЕНЕРАЛНИЯ ДЕЛИКТ КАТО ОСНОВАНИЕ НА ГРАЖДАНСКАТА ОТГОВОРНОСТ НА ЛЕКАРЯ

Мария Вълканова

УНС по медицинска етика и право, Катедра по соииална медицина и организация на здравеопазването, Факултет по обществено здравеопазване, Медицински университет - Варна

\title{
ADVERSE EVENTS IN MEDICINE IN THE CONTEXT OF THE GENERAL TORT LAW AS A BASIS FOR THE CIVIL LIABILITY OF PHYSICIANS
}

\author{
Maria Valkanova
}

Medical Ethics and Law Division, Department of Social Medicine and Health Care

Organisation, Faculty of Public Health, Medical Univercity of Varna

\section{PEЗЮME}

Медицинската професия е една от най-сложните форми на човешка дейност. Тя предполага специални знания, опит и отговорност. Рискът от възникване на неблагоприятни последиии в сферата на пациента обаче съпьтства нейното упражняване. С оглед преодоляване и минимизиране на т.нар. нежелани събития, които водят до вреди за пациента, от съществено значение е тяхното изследване, разбиране и класибициране както от медицинска, така и от юридическа гледна точка.

Ключови думи: нежелано събитие, безопасност на пациента, гражданска отговорност

\begin{abstract}
The medical profession is one of the most complex forms of human activity. It implies special knowledge, experience and responsibility. The risk of adverse effects in the patient's sphere accompanies its exercise. In order to overcome and minimize the so-called adverse events that cause harm to the patient, it is essential to study, understand and classify them both from a medical and a legal point of view.
\end{abstract}

Keywords: adverse event, patient safety, civil liability 
Медицината е една от най-сложните форми на човешка дейност. Тя предполага специални знания, отговорност и практически опит. Неслучайно тя попада сред професиите, източник на повишена опасност. В т. 7-9 на Постановление №6/1969 г. на Пленума на ВС е посочено, че източник на повишена опасност представляват такива занятия или дейности, при които и най-малкото незнание или немарливо изпълнение на занятието или дейността създава опасност за живота или за здравето на други лица. В тази връзка с оглед гарантиране на безопасността на пациента се говори за т.нар. нежелани събития при оказване на медицинска помощ.

В медицината и в правото обаче не съществува еднозначно разбиране и тълкуване на понятия, с които се означават различни по характер неблагоприятни последици, които могат да настъпят при или по повод оказване на медицинска помощ. В тази връзка с оглед постигане на адекватна превенция на т.нар. нежелани събития от съществено значение за практикуващите медицинска професия е да могат да дадат правна оценка на своите действия.

В настоящата статия по-конкретно се разглежда въпросът за нежеланите събития в медицината в контекста на гражданската деликтна юридическа отговорност.

В областта на медицината понятието „нежелано събитие“е термин, с който се означават различни по своя характер, произход и причини неблагоприятни последици, настъпили за пациента. Действащото гражданско законодателство на Република България обаче не познава подобно понятие, с което да свързва реализиране на гражданска деликтна отговорност. Понятието, което използва облигационното право и което се явява основание за генерализиране на гражданска деликтна отговорност, е деликт.

За тази цел, без да се претендира за изчерпателност, в настоящото изложение ще бъде направен опит да се посочат и откроят основните белези на тези две явления.

С цел координиране и разпространяване на инициативи за обезпечаване на пациентската безопасност Световната здравна организация (С3О) създаде Световния алианс за безопасност на пациентите. В тази връзка бе разработена и Международна класификация за безопасността на пациента. Тази класификация съдържа дефиниции на 297 термина в областта. Дефинирани са и семантичните връзки между понятията, а именно начинът, по който отделните понятия са свързани и следва да се тълкуват помежду си с оглед тяхното значение. Така според СЗО вредоносен инцидент или т.нар. нежелано събитие е инцидент, който е довел до вреди за пациента (12).

Възниква обаче въпросът дали всички неблагоприятни последици, настъпили за пациента, са резултат на правонарушение? Пита се: какво е съотношението между понятието нежелано събитие и правонарушението като юридически факт, обуславящ по-конкретно гражданската деликтна юридическа отговорност.

Съгласно генералното правило на чл. 45 от Закона за задълженията и договорите (З3Д) всеки е длъжен да поправи вредите, които виновно е причинил другиму, като се дължат всички вреди, които са пряка и непосредствена последица от увреждането.

Характерно за гражданската отговорност, която е единият от четирите вида юридическа отговорност в правото наред с наказателната, административнонаказателната и дисциплинарната отговорност, е, че за разлика от останалите три вида тя има имуществен характер. Или основната функция на тази отговорност е обезщетителна (3).

За да възникне обаче такава отговорност (за непозволено увреждане) за лекаря, е необходимо да се осъществи определен фактически състав. Този фактически състав се състои от следните предпоставки, които обуславят деликтната отговорност по смисъла на чл. 45 , ал. 1 от Закона за задълженията и договорите (З3Д).

Първо, трябва да е налице противоправно деяние на медицинския специалист, което може да се състои както в активни действия, така и в неправомерно бездействие от негова страна. Необходимо е действията, целящи диагностика и лечение на болния, да са извършени в противоречие с общоустановените методи на диагностика и лечение (2). Медицинският специалист следва да е нарушил задължението си да прилага методи и средства, които са утвърдени от медицинската наука и практика, както изрично изисква чл. 79 от Закона за здравето (33) (7). Текстьт на чл. 80 от 33 предвижда, че качеството на медицинската помощ се основава на медицински стандарти, утвърдени по реда на чл. 6, ал. 1 от Закона за лечебните заведения (ЗЛЗ) и Правилата за добра медицинска практика, приети и утвърдени по реда на чл. 5, т. 4 от Закона за съсловните организации на лекарите и лекарите по дентална медицина (ЗСОЛЛДМ). Установените основни принципи на правото на медицинска помощ в чл. 81, ал. 2 от 33 са своевременност, дос- 
татъчност и качество на медицинска помощ. Посочените разпоредби налагат извода, че противоправно е всяко поведение на лекар, което се намира в противоречие с утвърдените от медицинската наука и практика методи и технологии, с медицинските стандарти, утвърдени по реда на чл. 6, ал. 1 от 3ЛЗ и Правилата за добра медицинска практика, приети и утвърдени по реда на чл. 5, т. 4 от 3СОЛЛДМ в съответната област на медицината, с основните принципи на правото на медицинска помощ - своевременност, достатъчност и качество на медицинската помощ (8).

За да бъде т.нар. нежелано вредоносно събитие основание за реализиране на деликтна отговорност, е необходимо да е противоправно. Противоправността е съществен юридически факт от фактическия състав на отговорността в правото. В този смисъл е необходимо вредата да е последица от засягане на едно защитено от правото благо, обект на защитено абсолютно субективно право (5). Или връзката между едно събитие и вредата не е достатъчна, за да бъде то правно релевантно и на това основание да обоснове юридическа отговорност (5). В много случаи различни действия могат да причинят вреди. Съществуват и изключващи противоправността основания като крайна необходимост, задържане за предаване органите на властта, правно овластяване по сделка, акт на властнически орган / съдебно решение, административен акт, действие на съдия-изпълнител и пр. Следва да се отбележи, че информираното съгласие на пациента да бъде опериран или да му се приложат дадени методи за диагностициране на болестта, които засягат неговия телесен интегритет, давано на основание чл. 89, ал. 1 от Закона за здравето, не попада в категорията на изключващите противоправността основания. Това е така, защото по своята същност съгласието на пациента се дава не за да бъде увреден, а за да бъде лекуван, т.е. насочено е не към отрицателен, а към положителен резултат. Съгласието на пациента представлява приемане на възможните рискове от лекарската интервенция, обхваща всички нейни последици и означава действие на собствен риск, но не означава съгласие за лекарска грешка и нейните вредоносни последици $(2,7)$.

Второ, необходимо е да е настъпила вреда. Вредите са последици от засягане на субективни права и нарушаване на защитени от правото блага, които са предмет на субективни права (3).

Според С3О вредата предполага нарушение на структурата или функциите на тялото и/ или неблагоприятна последица, дължаща се на болест, нараняване, страдание, инвалидност и смърт и може да бъде физическа, социална или психологическа (12).

От даденото определение е видно, че под вреда се има предвид всяка неблагоприятна последица, настъпила в сферата на пациента. Прави впечатление обаче, че С3О не обвързва понятието за вреда неизменно с правонарушение. Това е така, защото не всяка вреда е последица от нарушаването на определени права. От юридическа гледна точка обаче вредите, които подлежат на обезщетяване и за които се носи отговорност, трябва да бъдат свързани с нарушение на права и с противоправни действия и резултати. В посочената дефиниция критерият не е паричната равностойност на вредите по смисъла на облигационното право, а приоритет е видът на засегнатото благо - именно нарушение на структура или функция на тялото на пациента, т.е. засягане на негови лични блага.

Според българското законодателство вредата при непозволено увреждане може да бъде два вида - имуществена и неимуществена.

Имуществени са вредите, които са оценими в пари. Имуществената вреда е разликата между имуществото на кредитора след засягането на благото и това, което би имал, ако нямаше засягане (3) Те биват претьрпени загуби (damnum emergens) и пропуснати ползи (lucrum cessans) (1). Вредите като претърпени загуби за пациента могат да се изразят в намаляване на имуществото на пациента поради направени от него разноски по лечението, по диагностициране на заболяването, по повод рехабилитация, заплащане на възнаграждението на придружител на болния или на болногледач, в това число и разноските по погребението при смърт на пациента (2). Имуществените вреди освен в причинени загуби могат да се изразят и в пропуснати ползи. Пропуснатата полза е това, с което щеше да се увеличи имуществото на пациента, ако не беше налице лекарска грешка. Такива пропуснати ползи ще са например неполучаването на трудово възнаграждение, на допълнителни трудови доходи за времето на увреждането, поради невъзможност да работи вследствие на погрешното лечение, както и неполучаването на издръжка от наследниците на починалото лице в резултат на лекарска грешка, при условие обаче че то приживе е издържало тези лица (2).

Според чл. 51, ал. 1 33Д всички имуществени вреди подлежат на обезщетяване в техния пълен 
размер. Пострадалото лице обаче трябва да докаже настьпването и размера им.

Неимуществени са вредите, които като последици от засягането на благата са неоценими в пари (3). Те се изразяват в претърпени болки и страдания, в отрицателни емоции, в лишаването на пациента от възможността да води качествен и пълноценен живот. Тези вреди нямат стойност и затова се определят от съда по справедливост (арг. от чл. 52 33Д). Но те също подлежат на доказване от пациента (т.нар. увредено лице). При присъждане на обезщетението съдът се ръководи от това дали увреденото лице в действителност е претърпяло болки и страдания и в каква близост се е намирало приживе с починалото лице (пациента). При смърт на пациента вследствие на непозволено увреждане право на обезщетение за неимуществени вреди имат неговите близки - родители, деца, съпруг $(3,6)$. Право на обезщетение за неимуществени вреди имат и лица, с които пострадалият е имал фактически отношения, аналогични на тези между низходящи, възходящи и между съпрузи (3). Когато е налице обаче само увреждане на здравето на пациента, без да е настъпила смърт, правото на обезщетение възниква единствено за него. Обезщетение за неимуществени вреди се дължи и при разгласяване на лекарска тайна, при нехуманно отношение към пациента и пр.

Според съдебната ни практика обезщетение за неимуществени вреди се дължи дори и в случаите, когато пострадалият не е изживял телесни болки и душевни страдания с ясно съзнание и не може да чувства никаква болка, нито да осмисли състоянието си поради обезболяващи средства или поради промени в централната и периферна нервна система, при които не може да преживява отрицателни емоции и усещания. Това разбиране кореспондира с разпоредбите на Конвенцията за правата на хората с увреждания (физически, интелектуални и сетивни) и хуманистичните постижения на цивилизацията в концепцията за ценността на човешката личност. Традиционното европейско разбиране е, че смисълът и ценността на човешкото съществуване не се свеждат до липсата на страдание, а включват възможности за радост, творчество, усъвършенстване на способностите, удовлетворение от постиженията, принос към обществото и най-вече човешко общуване (7)

Четвърто, необходимо е лекарят виновно да е причинил т.нар. нежелано събитие (2). При непозволеното увреждане, за разлика от наказателната отговорност, вината се предполага до до- казване на противното, т.е. в тежест на лекаря е да обори презумпцията за вина. Предполага се обаче небрежността, а не умисълът (3). Небрежността не е психическо отношение, а разминаване с дължимата мяра на поведение (3). Тя се знае и е известна предварително и затова при деликт небрежността се предполага.

Понятието за вина в гражданското право е неразривно свързано с понятието „дължима грижа". Това е един модел на поведение, наречен още „грижа на добрия стопанин” $(2,3)$. При определянето на дължимата грижа се изхожда не от поведението на конкретния лекар, а от грижата на определена категория специални субекти, каквито в случая са лекарите. Или при лекарските деликти дължимата грижа ще е налице, ако лекарят е положил необходимото внимание, старание и настойчивост, т.е. когато е положил всички усилия, на които е способен. При лекарските деликти обаче не е достатъчно приложението на този модел само. В този смисъл не са достатъчни само положените усилия. Или необходимо е да се приложи и т.нар. обективната теория относно дължимата грижа. При определени професии тя изисква не само полагане на усилие, но и притежаване на конкретни знания, умения и компетентност. Такава е и лекарската професия. Тук се изследва и изхожда от степента на грижа на професионалната група (3).

За да се освободи от отговорност, лекарят трябва да докаже, че е положил дължимата грижа (т.е. грижата на професионалната група), че е направил всичко необходимо, за да не бъде увреден пациентът му съобразно необходимите знания и умения, възприети и утвърдени от медицинската наука и практика, които следва да притежава всеки един добросъвестен лекар на негово място (2). Например, когато пациент постъпи в отделение по токсикология поради съмнение за алкохолно натравяне и премълчи за диабетно заболяване, изпадането впоследствие в състояние на диабетна кетоацидоза поради наличие на известно на болния заболяване диабет-инсулиновозависим, от което страда години, и последвалата обективна невъзможност да му бъде предоставено адекватно лечение, е резултатьт на неговото собствено поведение. Дежурният в отделение по токсикология нито е могъл, нито е бил длъжен по силата на конкретна нормативна разпоредба да назначи изследване на кръвната захар. Липсва нормативно задължение или правило за поведение, което да задължава лекар токсиколог да назначи изследване на нивата на „кръвната захар“ при пациенти със симптоматиката (9). 
И пето, вредите следва да се намират в пряка причинна връзка със съответното неправомерно виновно действие. Необходимо е да се докаже, че проведеното лечение или липсата му е сыществено условие за настыпване на вредата. В този смисъл, когато например за настъпването на смъртта е допринесъл и пътен инцидент, но се установи, че смъртта категорично е щяла да бъде избегната въпреки получените травми от ПТП при съответно адекватно оказана медицинска помощ, то лекарят не може да се оневини (10). Необходимо е наличие на каузалност между противоправното поведение на лекаря, от една страна, и настъпилия неблагоприятен резултат, от друга страна. Ако обаче пациент получи парализа на крайниците в резултат на инсулт и в същото време се установи, че е налице неправилно проведено лечение от лекуващия лекар, изразяващо се в неизвършване на спешна и неотложна операция във връзка с друго заболяване на пациента, няма да е налице причинна връзка между противоправното поведение по повод на операцията и вредата (парализата на крайниците) (11). Всяко явление е резултат от множество каузални фактори, но правно релевантната причинна връзка касае противоправно деяние, представляващо това условие, което с иманентна необходимост предизвиква настыпването на отрицателната последица в сферата на увреденото лице, т.е. деянието трябва да бъде условие, без което вредата не би настыпила и която закономерно произтича от деянието, а не е негово случайно следствие. Ако е известно, че при конкретните условия, при които деянието е извършено, обикновено не настъпва такъв резултат, то той е случайно следствие (4).

Въз основа на гореизложеното могат да бъдат направени следните изводи:

Първо, гражданският деликт като основание на гражданската деликтна отговорност на лекаря винаги се свързва с човешка волева дейност по смисъла на правото. Обратно, нежеланото събитие може да се дължи на различни причини, възможно е да е резултат на т.нар. допринасящи фактори (11) като например пропуски в организацията и функционирането на системата, пропуски, свързани с лоша организация на дежурствата, лоша екипна работа, недобра комуникация и пр.

Второ, противоправността на действията или бездействията, която е задължителна характеристика на юридическата отговорност, не е определяща за всяко едно нежелано събитие. В този смисъл последното може да е последица както на неправомерни виновни действия от страна на лекаря, така и на правомерни, извършени с оглед правилата на професията.

Следователно т.нар. нежелано събитие в медицината невинаги изпълва признаците на фактическия състав на деликта. То може да е в границите на допустимия професионален риск. Или неговото настъпване невинаги ще обоснове реализиране на деликтна гражданска отговорност.

\section{ЛИТЕРАТУРА}

1. Апостолов, И. Облигационно право. Част първа. Общо учение за облигацията, Coфия, 1990

2. Голева, П. Отговорността на лекаря за вреди, причинени на пациента

3. Калайджиев, А. Облигационно право, С., 2002, с. 347-348

4. Кожухаров, Ал. Облигационно право, София, 1958

5. Конов, Т. Основание на гражданската отговорност, София, 1995

6. Постановление №4 от 1961 на Пленума на $\mathrm{BC}$

7. Решение № 447 от 10.11.2014 г. по гр. д. № 683/2013 г. на Софийски окръжен съд

8. Решение№ 570/27.10.2010г. гр. Пазарджик

9. Решение № 904 от 01.07.2016 г. по гр. д. № 1808/2011 г. на окръжен съд - Варна

10. Решение № от 25.07.2013 г. по гр. д. № 60/2012 г. на Окръжен съд - Силистра

11. Решение № 16, 21.03.2012г., Бургаски апелативен съд, гражданско отделение

12. http://www.who.int/patientsafety/taxonomy/ icps_full_report.pdf?ua=1

Адрес за кореспондениия: Мария Ввлканова

Катедра по сочиална медицина и организация на здравеопазването,

УНС по медицинска етика и право,

Медицински университет - Варна

ул. Марин Дринов 55

e-mail:m.valkanova02@gmail.com 